\title{
ÉRTÁGÍTÓBETÉTEK LÉZERSUGARAS HEGESZTÉSE
}

\section{LASER BEAM WELDING OF STENTS}

\author{
Dobránszky János $^{1}$, Bitay Enikő ${ }^{2}$, Major László ${ }^{3}$, Nagy Péter ${ }^{4}$ \\ ${ }^{I}$ MTA-BME Kompozittechnológiai Kutatócsoport, 1111 Budapest, Müegyetem rak- \\ part3.Dobranszky.Janos@eik.bme.hu \\ ${ }^{2}$ Sapientia Erdélyi Magyar Tudományegyetem, Müszaki és Humántudományi Kar, \\ Gépészmérnöki Tanszék, Marosvásárhely, 540485 Târgu-Mureş, O.p. 9, C.p. 4. \\ ebitay@ms.sapientia.ro
${ }^{3}$ Magyar Honvédség Egészségügyi Központ, Honvédkórház, 1134 Budapest, Róbert Károlykörút 44.ml@cvi.hu
${ }^{4}$ BME Gépészmérnöki Kar, Anyagtudomány és Technológia Tanszék, 1111 Buda- pest, Müegyetem rakpart3.npeter@eik.bme.hu

\begin{abstract}
The authors give an overview about the application of welding, mainly the laser welding related to the fabrication of stents. The paper demonstrates the welding of markers and the stents, which are made of wire.
\end{abstract}

Keywords: laser welding, stent.

\section{Összefoglalás}

A cikkben a szerzők áttekintést adnak az értágítóbetétek gyártásához kapcsolódó hegesztési, főleg lézersugaras hegesztési alkalmazásokról. Bemutatják a markerek hegesztését és a huzalból készült értágítóbetétek gyártását.

Kulcsszavak: lézersugaras hegesztés, értágitóbetét.

\section{Bevezetés}

A szív koszorúereinek és a perifériás ereknek a szükülete az egész világon az egyik leggyakoribb népbetegség. Az érfal belső részén lerakódások jönnek létre, amelyek idővel elmeszesednek; így csökkentik az erek átmérőjét és gyengítik rugalmasságát. A gyógyászatban jelenleg a legfontosabb értágítási módszer az értágítóbetét (angolból átvett nevén: sztent) beültetése. Katéterekkel a csőszerü fém- vagy újabban felszívódó müanyaghálót betolják az érszükületbe, és ott a sztent fajtájától függő módon kitágítják; az 1. ábra szemlélteti a ballonos tágítást. A sztent beültetésének ered- ményeképpen megnyílik az út a vér áramlása számára.

Az első értágítóbetétek az 1980-as évek végén kerültek forgalomba. A Wallstent nagy szilárdságú, merev rugózású $\mathrm{Co}-\mathrm{Cr}$ Ni-Mo-ötvözethuzalból készült. Az 1990-as évek végére a Co-Cr-ötvözetek és a $\mathrm{Ni}$-Tiötvözetek mellett sok más anyagot is kipróbáltak, ugyanis a ballonos tágítású sztentek az előzőeknél jóval lágyabb alapanyagot igényelnek. A fô alapanyaggá az ausztenites acél vált (amerikai szabványos jelölése: AISI 316L), de több más anyag is színre került, például az arany, a tantál, a 10\% irídiumot tartalmazó Pt-ötvözet és a nióbium. 


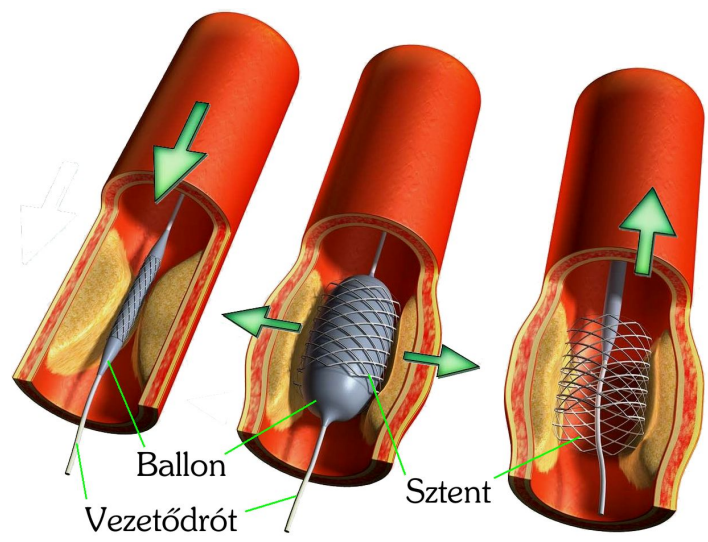

1. ábra. Az értágitás jellegzetes szakaszai ballonos tágitású értágitóbetét alkalmazásakor

Az alapanyagok és bevonatanyagok mellett az értágítóbetétek gyártási módszerei is nagy fejlődésen mentek keresztül. A sztentek gyártásában már kb. 20 éve a lézersugaras vágás az alapvető gyártási eljárás, de a hegesztés és azon belül a lézersugaras hegesztés mind a mai napig jelen van ebben a nagy pontosságú mikromegmunkálásra alapozott iparágban. Jelen dolgozatban a lézersugaras hegesztés sztentgyártási alkalmazásait tekintjük át.

\section{Lézersugaras hegesztés a szten- tek markereinek kialakítására}

A sztentek körül forgó innovációs és kutatási erőfeszítések folyamatában az orvosi és az anyagtechnológiai szakma kezdettől szoros kapcsolatban állt; csak így lehetett az orvosi igényeket és tapasztalatokat a lehető leghatékonyabban, a zsákutcák gyors kikerülésével müszakilag megvalósítani. Erre jó példaként szolgál a láthatóság - amely egy fontos funkcionális sztenttulajdonság - területén végbement fejlődés. A sztentek fémbordájának vastagsága a kezdeti 200 mikronról átlagosan 70 mikrométerre csökkent az orvosi igényeknek megfelelöen, ez azonban erősen lerontotta az orvos számára ugyancsak fontos, röntgensugár alatti láthatóságot. Erre a vastagságcsökkenés okozta mellékhatásra az a müszaki válasz született, hogy arany-, tantál- vagy platinamarkereket hegesztettek a sztent végeire lézersugaras hegesztéssel.

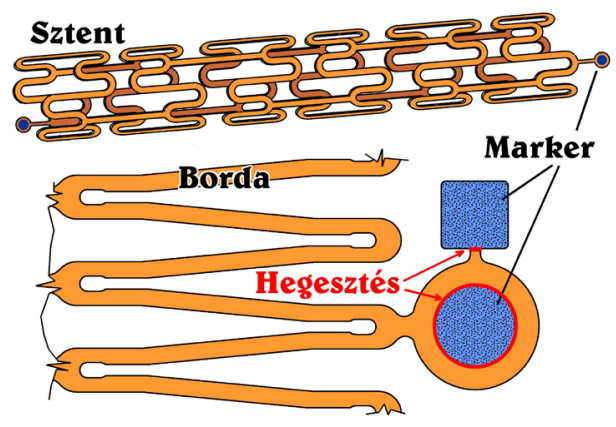

2. ábra. Markerkoncepció magnéziumsztentre; az alapábra forrása: [1]

A 2. ábrán a Medtronic cég által szabadalmaztatott [1], lézersugaras hegesztéssel kialakított tantálmarkeres magnéziumsztent vázlata látható. A markerek különösen fontosak a gyenge láthatóságú nitinolsztentek (3. ábra [2, 10] és 4. ábra [3]), valamint a biológiailag felszívódónak tekintett magnézium és politejsav anyagú sztentek esetében. A markerek eltérö fémes anyaga viszont korróziós kockázatot jelent; ezt tanúsítja az 5. ábra [4]. 
a)
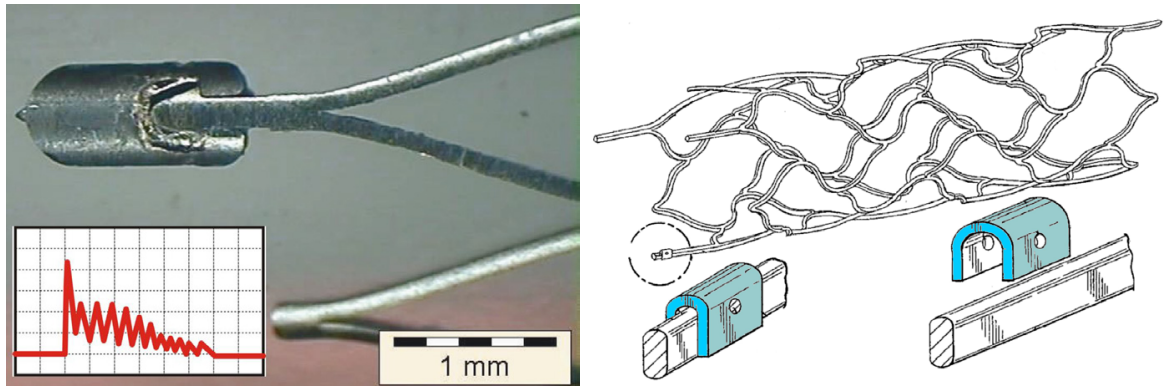

b)

3.ábra. a) Ta-marker nitinolsztentre hegesztve LASAG Easywelder SLS 200 CL32 típusú lézersugaras berendezéssel; $65 \mathrm{~mJ}$ impulzusenergia, $100 \mathrm{~mm} / \mathrm{min}$ hegesztési sebesség, modulált „trailing edge” impulzusalak [2]; b) Lézersugárral hegesztett Ta-, Zr-, Au-, Pt-marker rögzítési módjának vázlata egy egészen új szabadalomból [10]
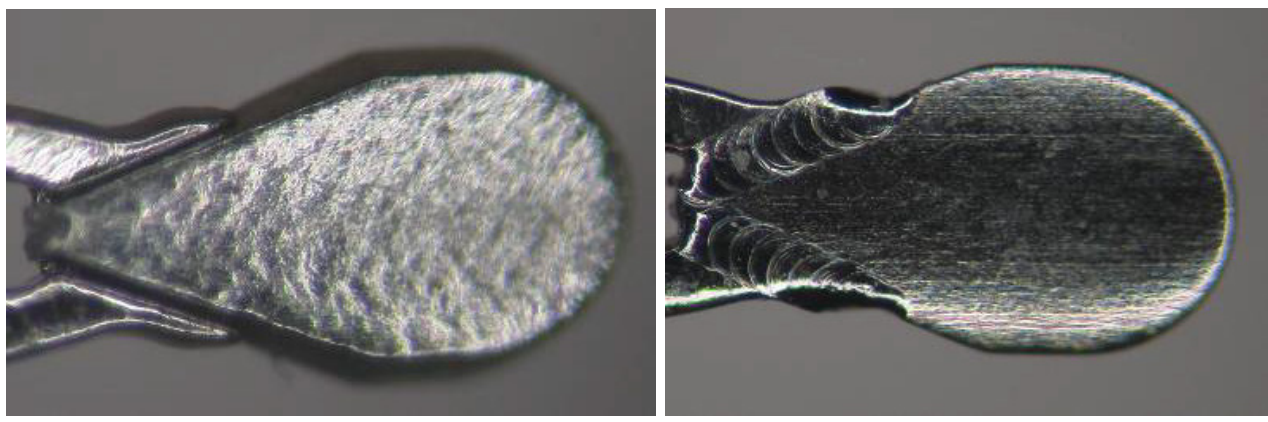

4. ábra. Ta-marker a sztentbe való behegesztés elött és után [3]; a varratszélesség 0,10 mm
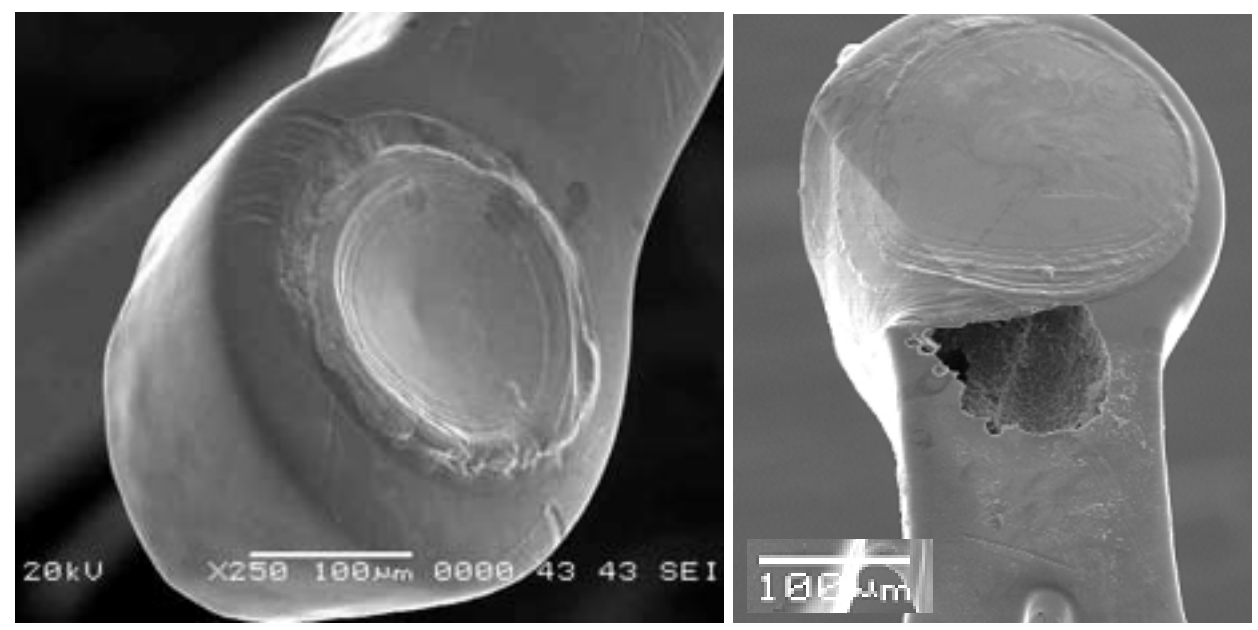

5. ábra. Platinamarker nitinolsztentbe hegesztve korróziós vizsgálat elött és után [4] 


\section{A sztentek hálós szerkezetének kialakítása hegesztéssel}

A mikrohegesztés azoknál az értágítóbetéteknél jelenik meg a gyártási müveletek sorában, amelyek nem egy elöre gyártott, varrat nélküli cső lézersugaras vágásával készülnek, hanem a kiinduló előgyártmány huzal vagy perforált lemez vagy többrétegü lemezből hengerített és lézersugaras hosszvarrathegesztéssel gyártott cső [12]. Ennek nagy előnyeként hangsúlyozzák a huzalsztentek gyártói a bordák keresztmetszetének kör alakját. Ilyenkor a lézersugaras hegesztés a bordázat csomó-

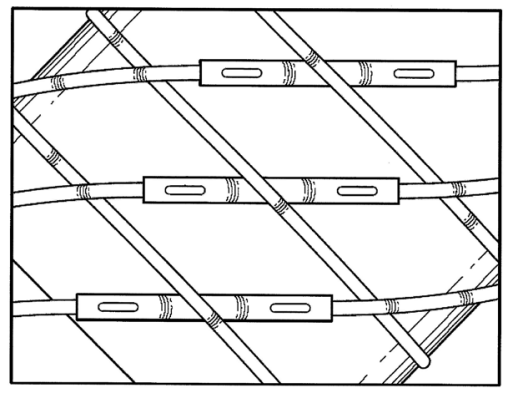

6. ábra. Huzalvégek tompakötése a mandzsetta lézersugaras áthegesztésével; az eredeti képek forrása: [5]
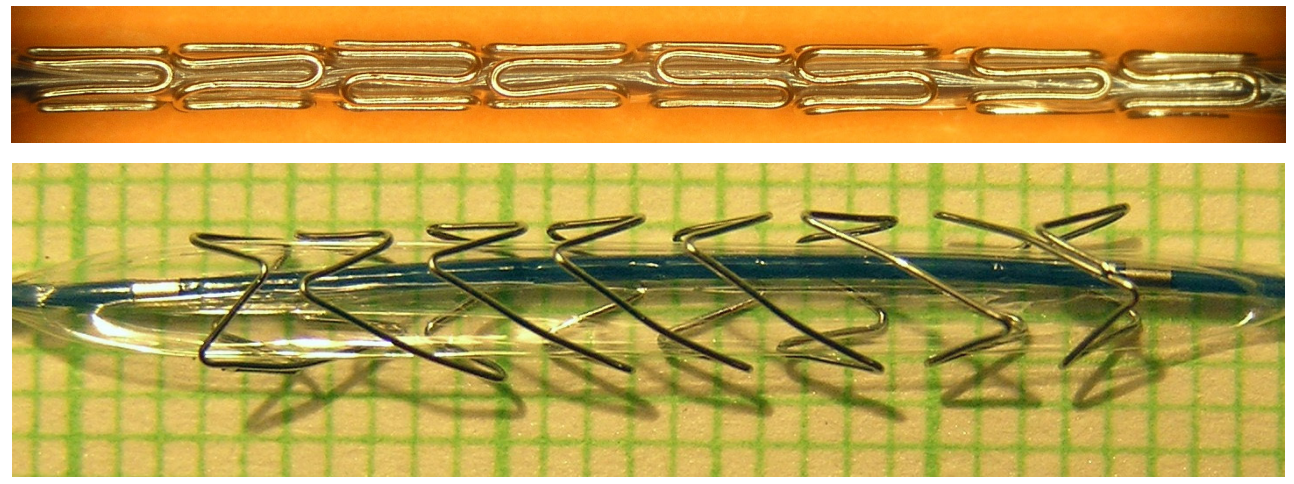

7. ábra. Az egyetlen huzalból hajtogatott Horus sztent huzalvégeit lézersugaras hegesztéssel rögzitették. A képen feltágitás elött és az utáni állapotában látható

A hegesztést alkalmazó gyártók száma csekély, igazi nagy gyártó csak egy van közöttük: a Medtronic. A Medtronic

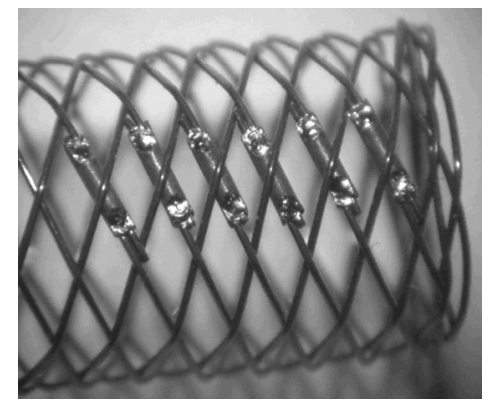

pontjai és a huzalvégek rögzítésére vagy tompakötéssel egymáshoz való toldására szolgál. A szuperrugalmas nitinol huzalkötegeiből kialakított öntáguló hálók szúrós huzalvégeinek mandzsettás tompakötéseit lézersugaras hegesztéssel készítik a perifériás erekbe szánt Supera sztenten az Idev Technologies szabadalma szerint; a mandzsetták anyaga ausztenites acél (6. ábra) [5]. A huzal alapanyagot preferálták a Horus koszorúérsztent gyártói is, de itt mindössze a két huzalvéget rögzítették lézersugaras hegesztéssel a cikcakkban feltekert bordázaton (7. ábra). 
a nem cső elögyártmányból valóban nagy tömegben (többmilliós darabszám) gyártott sztentek. A kezdetben 316L acélból, majd az ezt felváltó L605-ös Co-Cr ötvözet anyagú huzalból szinuszosan meghajtogatott szerkezet csomópontjait lézersugaras hegesztéssel rögzítették (8. ábra) [6].
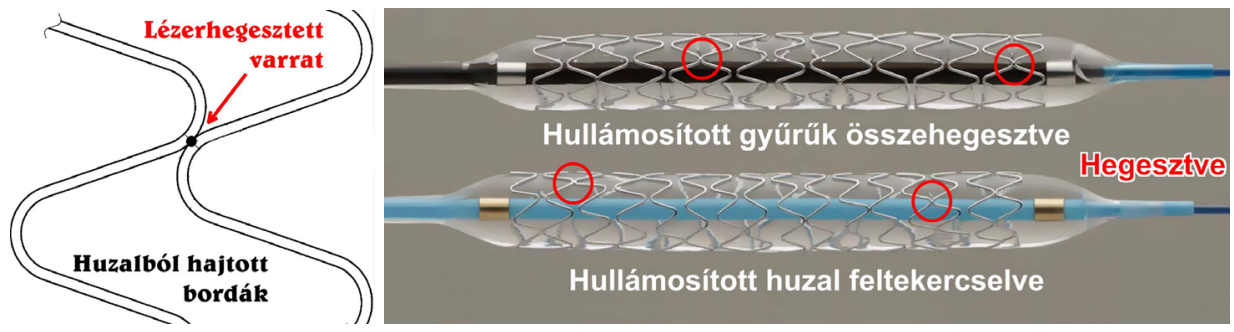

8. ábra. A huzalból hajtogatott Medtronic sztentek lézersugárral hegesztett csomópontja [6, 7]

a)

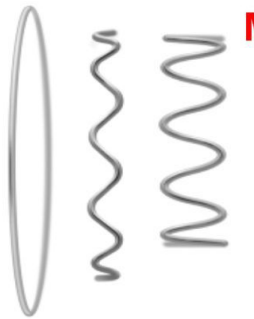

\section{Moduláris felépítés}
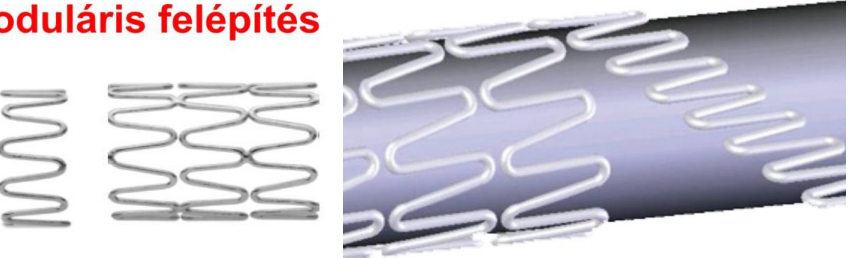

Folyamatos tekercselés

b)

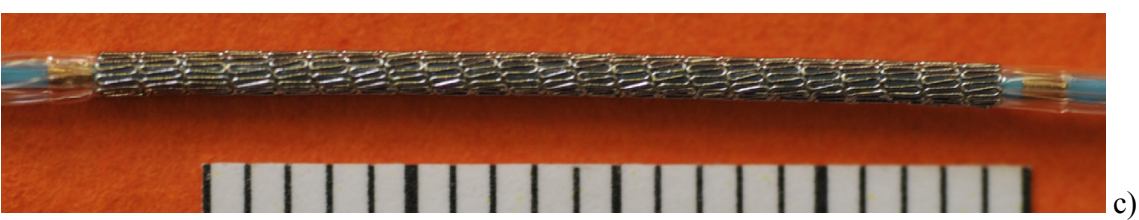

d)
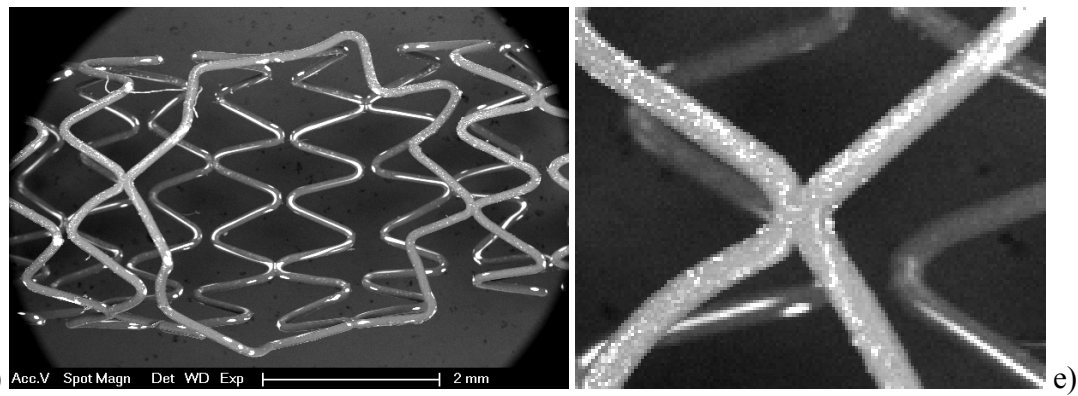

9. ábra. A Medtronic szegmenses (a) és folyamatos tekercselésü (b) huzalsztentjeinek szerkezeti vázlata [8]. Egy Resolute Integrity 3,0×22 mm-es sztent feltágitás elött (c), egy részlete az után (d) és egy hegesztési varrata (e)

Ezeknél a sztenteknél sokáig egyedi gyürüket hullámosítottak, és szegmensenként hegesztették össze, de az Integrity sztent már egy „szinuszosan” hullámosított folyamatos huzal ,menet a menet mellé” módon végzett feltekercselésével készült. 
Minden negyedik csomópontot és a két huzalvéget hegesztik lézersugaras hegesztéssel (9. ábra) [7, 8]. Koncepció és prototípus szintjén már léteznek a lézersugárral hegesztett maghuzalos huzalsztentek, továbbá frissiben szabadalmi oltalmat nyertek olyan gyógyszerkibocsátó sztentek is, amelyeknél nem a fémre felvitt polimer bevonatból oldódik ki a hatóanyag, hanem közvetlenül a fémböl. Ezeknél a lézersugárral hegesztett bordázat radiális tengelyü furatokkal perforált cső, amelybe betölthetö a gyógyszer; ezek a gyógyszerrel töltött sztentek (angol nevük: DFS, drug filled stents) [11].

\section{A Tentaur Flex lézerhegesztett huzalsztent kifejlesztése}

A Magyarországon és Oroszországban 1995-től több mint tíz éven át forgalmazott

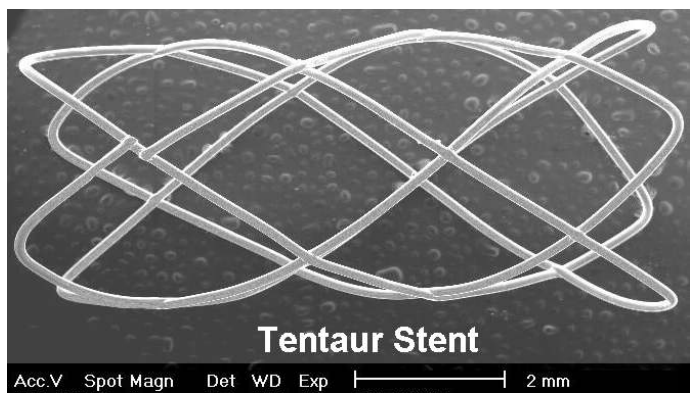

a) és több ezer példányban beültetett Tentaur sztent (10. ábra) első változata aranyhuzalból készült.

A huzalkeresztezések 17 csomópontját lánghegesztéssel, később ellenállásdudorhegesztéssel rögzítették. Az aranyhuzalt felváltotta az ausztenites korrózióálló acél.

A 145 mikrométer átmérőjü huzalra aranybevonat került (11. ábra), majd a Tentaur sztentről is lemaradt az aranybevonat, noha egyáltalán nem mutatott kedvezőtlen hatást. 1998-tól 2006-ig a Tentaur sztent sok bevonatolási kutatás alanya volt: készült TiN (12. ábra), SiC, TiC, szilikon, amorf és gyémántszerü szén (DLC-) bevonattal, és más passzív bevonatok mellett hatóanyag-kibocsátó változatban is, Colchicin-bevonattal.

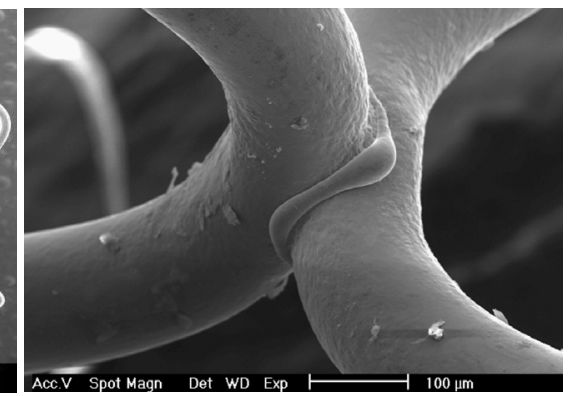

b)

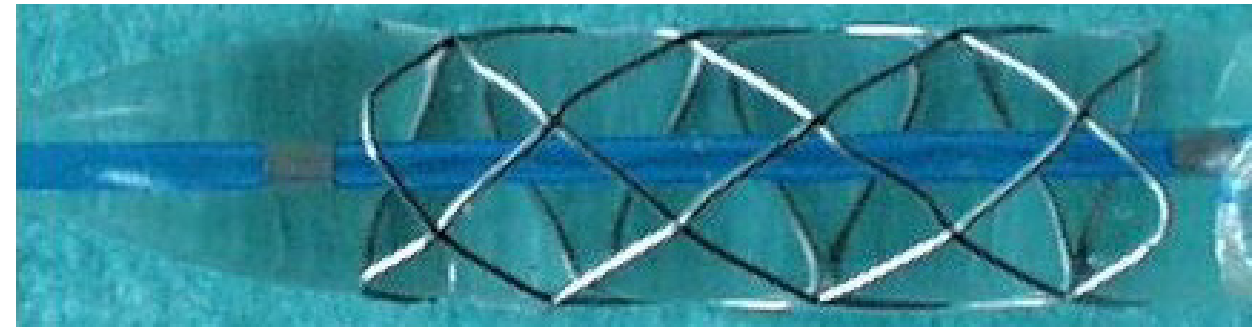

c)

10. ábra. Az ellenállás-dudorhegesztéssel gyártott Tentaur sztent gyártási állapotban (a), egyik hegesztett csomópontja (b) és egy példánya ballonkatéterrel tágitva 

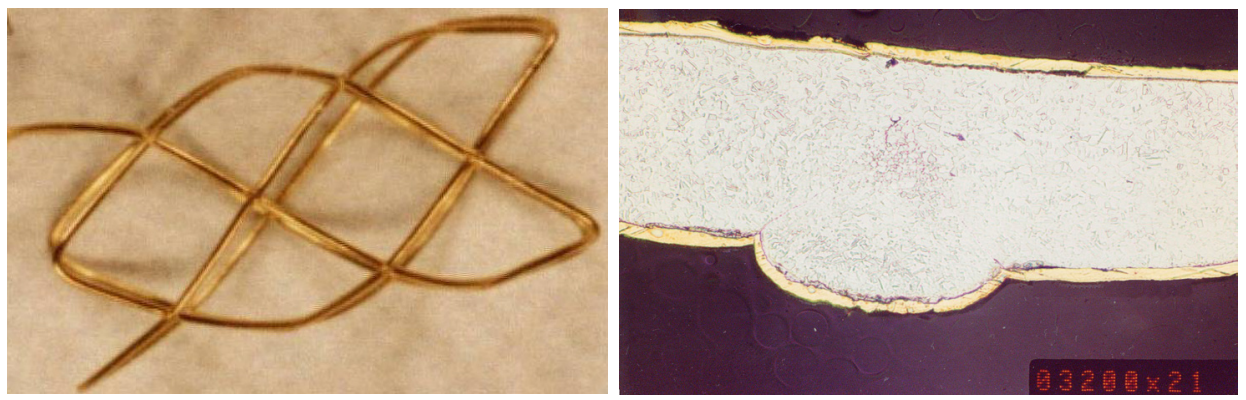

11. ábra. Aranybevonatos Tentaur sztent, valamint egy hegesztési varratának metszete (1998)

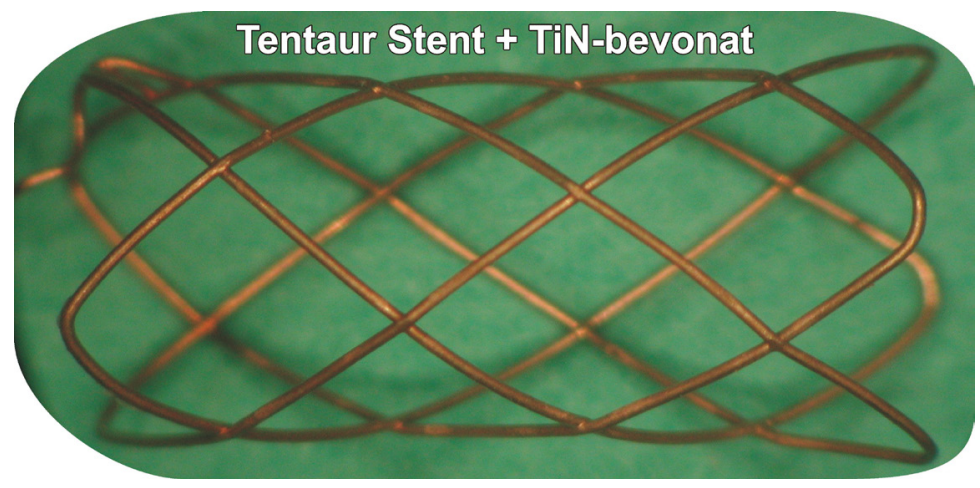

12. ábra. A Tentaur sztent titán-nitrid bevonattal készült változata (2002)

A Tentaur sztent kör keresztmetszete klinikailag nagyon kedvező volt, de a dudorhegesztett szerkezet nem volt kellően flexibilis - értsd: rugalmasan hajlékony - a hegesztett csomópontok merevítő hatása következtében. A flexibilitás hiánya különösen a hosszú sztenteknél kellemetlen. Ennek kiküszöbölésére a 2000-es évek közepén a Driver sztentet felváltó Integrity sztent kapcsán fentebb ismertetett koncepciót dolgoztuk ki már 1999-ben: a szinuszos hajtogatást és a csomópontok egy részének, illetve a huzalvégeknek a hegesztéssel való rögzítését. $\mathrm{Az}$ így megtervezett flexibilis sztent, a 13. ábrán látható Tentaur Flex sztent sokáig csak papíron létezett, de amikor sikerült lézersugaras mikrohegesztési lehetőséget találni Magyarországon, akkor végre elkészültek az első prototípusok
0,145 mm átmérőjü, AISI 316L típusú ausztenites acélhuzalból (14. ábra) [9].

A lézersugaras mikrohegesztési lehetőségek kiszélesedése a Lasersystems $\mathrm{Kft}$. ez irányú támogatásának volt köszönhető 2006-tól kezdődően. Ekkor újra napirendre került a lézersugárral hegesztett huzalsztentek fejlesztése. A kísérletekben $0,20 \mathrm{~mm}$ átméröjü ausztenites acélhuzalt használtunk. A hegesztést TRUMPF HL $124 \mathrm{P}$ típusú berendezésen végeztük, amelynek müszaki jellemzői és a véglehegesztés optimalizált technológiai tényezői a következők:

-lézerteljesítmény: $\quad 120 \mathrm{~W}$;

- maximális impulzusteljesítmény: $5 \mathrm{~kW}$;

-impulzusenergia: $\quad 0,1-50 \mathrm{~J}$;

-impulzushossz: $\quad 0,3-20 \mathrm{~ms}$;

-sugárminőség: $\quad 16 \mathrm{~mm} \cdot \mathrm{mrad}$. 


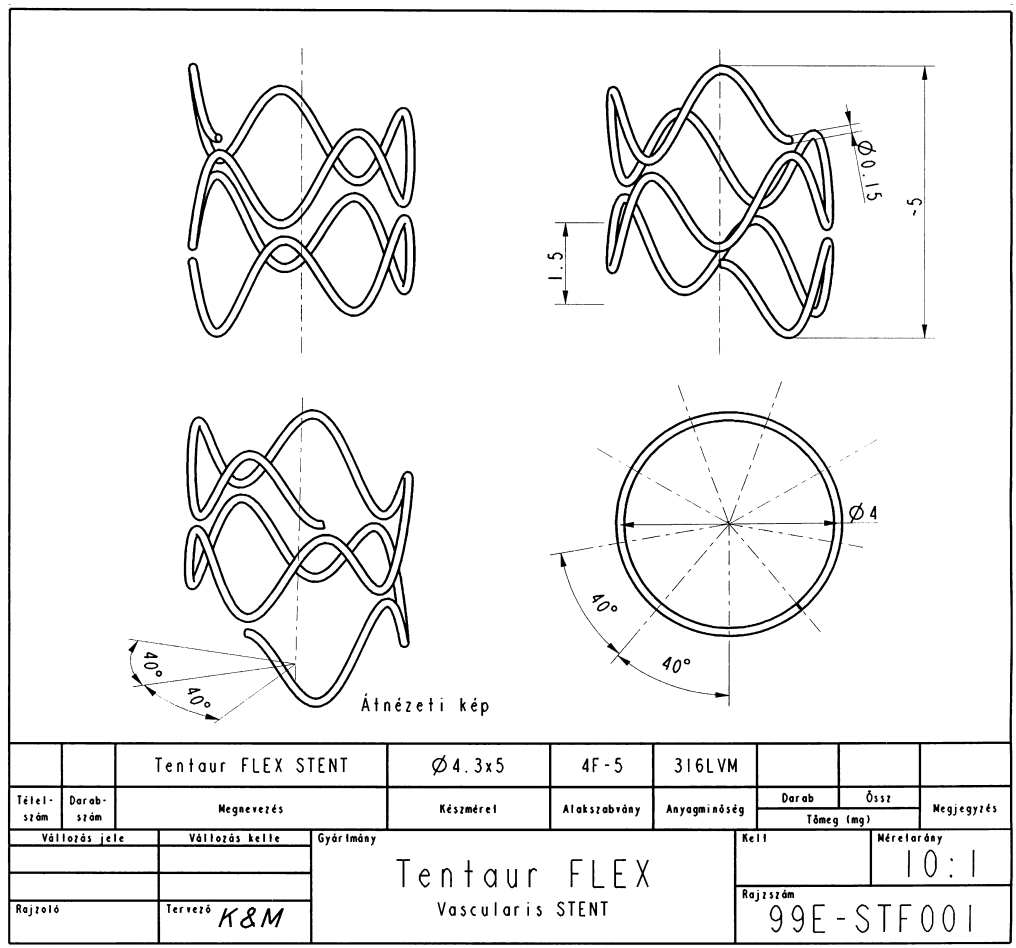

13. ábra. A koncepciójában 1999-ben megszületett Tentaur Flex sztent gyártási rajza
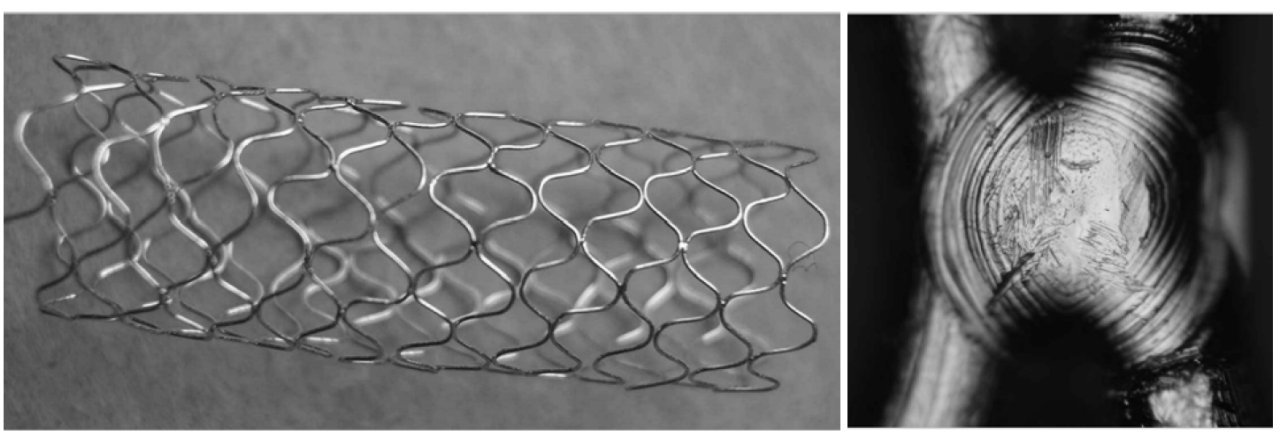

14. ábra. A lézersugaras hegesztéssel gyártott Tentaur Flex sztent prototípusa 2005-böl és egyik hegesztési varrata; a huzalátmérö 145 mikrométer

Az érintkező huzalívek lézersugaras hegesztésekor fellépő egyik hibaforrás az ömledék tölcséres beszívódása a plazmanyomás miatt (15.a ábra). A beszívódás megszüntetésére (15.b ábra) jó megoldás az impulzusalak-szabályozás - amelynek lényege az, hogy az impulzus időtartama alatt vezérelten változik a teljesítmény vagy az általunk használt fókuszeltolás. 
a)
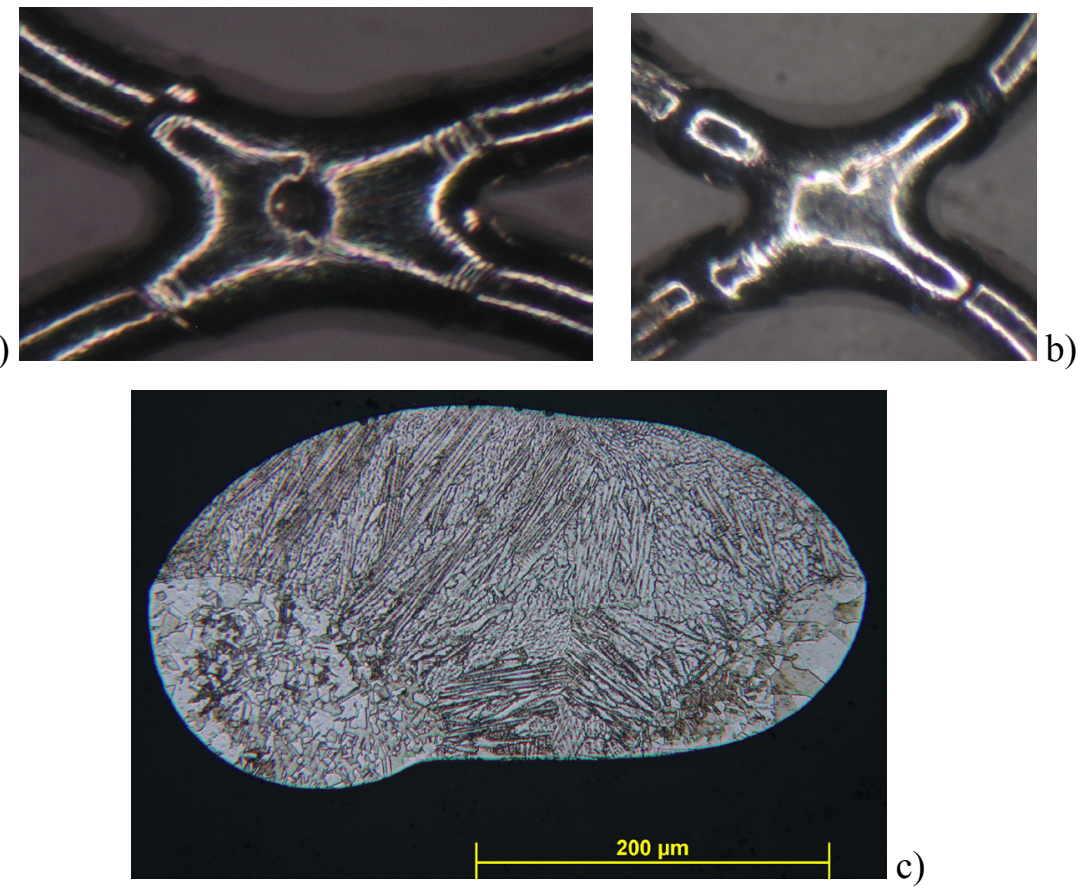

15. ábra. A Tentaur Flex sztent egy oldalról végzett lézersugaras hegesztési technológiájában ki kellett küszöbölni a tölcséres beszivódás jellegü kötéshibát (a). A hibamentes varrat a b) képen, annak maratott keresztmetszeti csiszolata a c) képen látható

a)

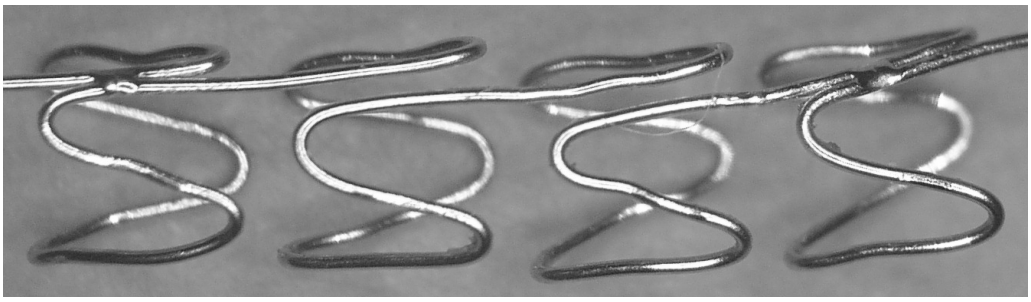

a)

b)
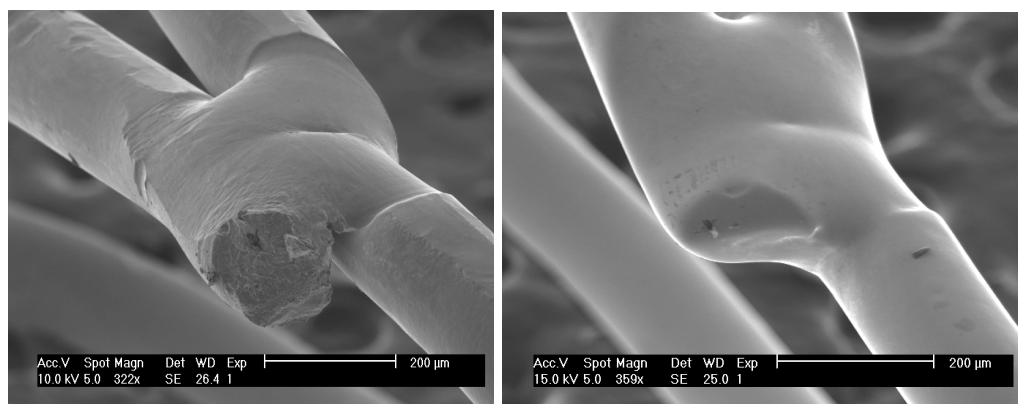

c)

16. ábra. A lézersugaras hegesztéssel gyártott Tentaur Flex sztent prototipusa 2005-böl és egyik hegesztési varrata; a huzalátmérö 145 mikrométer 
A 16.a ábrán látható, $13 \mathrm{~mm}$ hosszúságú Tentaur Flex sztent hegesztéstechnológiai tényezői a következők a TRUMPF HL 124 P típusú lézerberendezésen:

- Foltátmérő

$1 \mathrm{~mm}$;

- Teljesítmény

$0,72 \mathrm{~kW}$;

- Impulzusidő

2,4 ms;

- Lövések száma

$2 \mathrm{db} /$ ciklus;

- Frekvencia

$4 \mathrm{kHz}$;

- Energia

$1,7 \mathrm{~J}$

- Átlagteljesítmény

$6 \mathrm{~W}$.

A 16.b-c ábrán az egyik lehegesztett huzalvég hegesztést követő elektropolírozás előtti és azt követő állapota látható.

\section{Következtetések}

A lézersugaras hegesztés mindig is fontos gyártástechnológiai választási lehetőséget kínált az értágítóbetétek gyártásában, és ez - értékelésünk - szerint a jövőben is így lesz.

\section{Köszönetnyilvánítás}

Bitay Enikő személyéhez kötődően a kutatás az EU és Magyarország támogatásával a TÁMOP 4.2.4.A/1-11-1-2012-0001 azonosítószámú „Nemzeti Kiválóság Program - Hazai hallgatói, illetve kutatói személyi támogatást biztosító rendszer kidolgozása és működtetése országos program" címü kiemelt projekt keretei között valósult meg.

\section{Szakirodalmi hivatkozások}

[1] Allen, J., Birdsall, M.J. (Medtronic): Bioabsorbable Stent Having a Radiopaque Marker. US Patent 20090204203 A1 (2009)

[2] Use of pulsed Nd:YAG lasers in medical industry. LASAG Medical Industry/DU/06 (2006).

[3] Siekmeyer, G., Steegmüller, R., Schrader, B., Hegel, A., Strobel, M., Schuessler: Novel Micro-Joining Techniques to Improve Stent Radiopacity. A Comparison of Welding and Riveting Processes. Proceedings from the
Materials \& Processes for Medical Devices Conference 2005, ASM 2006. 57-62.

[4] Steegmüller, R., Strobel, M., Flaxmeier, E., Schuessler, A.: Micro-Welding for Improved Radiopacity of Nitinol-Stents. SMST-2004: Proc. of the Internat. Conf. on Shape Memory and Superelastic Technologies, Baden-Baden, October 3-4, 2004. S.591-595.

[5] Sheldon J, Booth R, Bueche K (Idev Technologies): Methods for Securing Strand Ends and the Resulting Devices. US Patent 20080290076 A1 (2008).

[6] Boyle, W.J. (Medtronic): Welded sinusoidal wave stent. US Patent 6136023 (2000).

[7] Rha, S-W: Current \& Future Stent Design for Drug-eluting Stent - Focused on the Updated Resolute Program http://www.summitmd.com/pdf/pdf/16.Seung-WoonRha.pdf (2013-10-23).

[8] Wilcox, J.N.: A Unique Approach to Creating a Polymer Free Stent The Medtronic Drug Filled Stent Program. ICI 2012, December 3-4, 2012. http://www.icimeeting.com/2012/images/stor ies/PDF/1400_Wilcox_Tue_A.pdf (201310-23).

[9] Szabó, B., Dobránszky, J., Major, L., Nyitrai, Zs.: Development and Micro Manufacturing of Coronary Stents in Hungary. 4M: Workshop on Multi-Material Micro Manufacturing Focusing on Metal Processing and Metrology, Budapest, 23-24 March 2006, BUTE Department of Manufacturing Engineering, Budapest 2006. 59-65.

[10] Codman \& Shurtleff, inc. (Raynham, MA, US): Radiopaque markers for implantable stents and methods for manufacturing the same. Patent application number: 20130131785 (2013).

[11] Bienvenu, R., Mitchell, J., Thompson, D. (Medtronic Vasculsr): Hollow drug-filled stent and method of forming hollow durgfilled stent. Patent application number: 20130274867, Közzététel dátuma: 2013-1017.

[12] Stinson, J.S. (Boston Scientific): Methods of making medical devices. US Patent 7574799 B2 (2009). 